\title{
Hydrogen peroxide mediates doxorubicin-induced transglutaminase 2 expression in PC-14 human lung cancer cell line
}

\author{
Jeong A Han ${ }^{1}$ and Sang Chul Park ${ }^{2,3}$ \\ 1 Department of Biochemistry, Kangwon National University College of Medicine \\ Choonchun 200-701, Korea \\ 2 Department of Biochemistry, Seoul National University College of Medicine, Seoul \\ 110-799, Korea \\ 3 Corresponding author: Tel, +82-2-740-8244; Fax, +82-2-744-4534; \\ E-mail, scpark@plaza.snu.ac.kr
}

Accepted 20 April 1999

Abbreviations: TGase, transglutaminase; MDR, multidrug resistance; DCF, 2,7dichlorofluorescein; NAC, N-acetylcysteine; GSH, glutathione; ROS, reactive oxygen species

\begin{abstract}
Increased expression of Transglutaminases 2 (TGase 2, TGase C) was observed in PC-14 human lung cancer cells in association with doxorubicin resistance and the reduction of the enzyme expression was correlated with the increasing cytotoxicity of the drug (Han and Park, 1999). Hydrogen peroxide was suggested to be a key mediator for doxorubicin-induced DNA fragmentation leading to apoptosis. A possible role of hydrogen peroxide as a putative mediator of TGase 2 expression in the doxorubicin sensitive PC-14 cells was examined. TGase 2 expression was increased in PC-14 cells treated with doxorubicin in a dose-dependent manner resulting in the concomitant increase of reactive oxygen species. The rise of TGase 2 expression by doxorubicin treatment was inhibited by $\mathrm{N}$-acetylcysteine or glutathione treatment, while direct addition of hydrogen peroxide to PC-14 cells induced TGase 2 expression. These results suggest that generation of hydrogen peroxide induced by doxorubicin treatment is one of the key factors in an enhancement of TGase 2 expression in PC-14 cells.
\end{abstract}

Keywords: Transglutaminase 2, Hydrogen peroxide, Doxorubicin, PC-14 cells

\section{Introduction}

Doxorubicin is one of the most widely used chemotherapeutic agents. However, the cross-resistance to unexposed drugs which share no obvious structural resemblance with doxorubicin has been a big problem in the doxorubicin-based chemotherapy. This multidrug resistance (MDR) phenomenon frequently occurred in using alkaloid com-pounds and antibiotics including anthracyclines such as doxorubicin and daunomycin, vinca alkaloids, actinomycin $\mathrm{D}$, etoposide or paclitaxel (Beck, 1987). The MDR pheno-type has been partially explained in connection with a variety of biological factors; overexpression of $170 \mathrm{kDa}$ P-glycoprotein or 190 kDa multidrug resistance-associated protein (Beck, 1987; Marquartdt et al., 1990; Cole et al., 1992), quantitative or qualitative alterations of target molecule, topoisomerase II (Ross et al., 1984; Harker et al., 1991; Sullivan et al., 1993), increased drug detoxifying systems, such as glutathione, $\gamma$-glutamylcysteine synthetase or $\gamma$ glutamyl transpeptidase (Hamilton et al., 1985; Godwin et al., 1992), decreased susceptibility to oxygen free radicals, which is associated with increased superoxide dismutase, glutathione peroxidase or anionic glutathione transferase (Batist et al., 1986; Mimnaugh et al., 1989), the increased activity of protein kinase $\mathrm{C}$ (Fine et al., 1988; Lee et al., 1992), or overexpression of c-Fos (Scanlon et al., 1991; Scanlon et al., 1994). Recently, overexpression of TGase 2 was suggested to be related with the resistance to doxorubicin (Mehta, 1994; Han and Park, 1999).

Transglutaminases (EC 2.3.2.13; TGases) are $\mathrm{Ca}^{2+}$ dependent enzymes that carry out acyl-transfer reactions between $\gamma$-carboxamide groups of peptide-bound glutamine residues and $\varepsilon$-amino groups of peptide-bound lysine residues or primary amino groups of polyamines, resulting in the isopeptide bond formation (Folk, 1980; Folk and Chung, 1985; Davies et al., 1988). Among the several isozymes, TGase 2 is a ubiquitous enzyme implicated in diverse cellular functions including differentiation (Birckbichler et al., 1976; Scott et al., 1982), inhibition of cell growth (Cai et al., 1991; Mian et al., 1995; Katoh et al., 1996), cell adhesion (Byrd and Licht, 1987; Gentile et al., 1992), receptor-mediated endocytosis (Davies et al., 1980; Julian et al., 1983), secretion (Bungay et al., 1984; Fesus et al., 1985; Bungay et al., 1986), apoptosis (Fesus et al., 1987; Piacentini et al., 1991) and receptormediated intracellular signaling (Lee et al., 1989; Nakaoka et al., 1994; Feng et al., 1996).

In addition, increased TGase 2 expression was observed in doxorubicin-resistant MCF-7 human breast cancer cells or PC-14 human lung cancer cells (Mehta, 1994; Han and Park, 1999). But the precise mechanism by which doxorubicin induced TGase 2 expression was not clearly understood. Doxorubicin has been known to generate 
reactive oxygen species (ROS) due to one electron transfer from its quinone redox cycling, which modify membrane lipids, DNA and proteins (Slater, 1984). Recently, it was reported that topoisomerase II modified by doxorubicin was bound to DNA covalently and thereby DNA breaks were ensued (Ross et al., 1984). Hydrogen peroxide was suggested to be a key mediator for doxorubicin-induced DNA fragmentation leading to apoptosis (Simizu et al., 1998). Association of two doxorubicininduced cellular events may provide possible mechanism of regulation of TGase 2 expression in PC14 cells. In this study, a possibility of hydrogen peroxide generated in the redox cycling of doxorubicin as a putative mediator of TGase 2 expression in the doxorubicin sensitive PC-14 cells was examined.

\section{Materials and methods}

\section{Materials}

RPMI 1640 media, fetal bovine serum, penicillin G sodium/ streptomycin sulfate were purchased from GIBCO BRL (Geithersburg, MD). $\left[1,4-{ }^{14} \mathrm{C}\right]$ putrescine and enhanced chemiluminescence (ECL) kit were purchased from Amersham (Little Chalfont, UK). 2,7-Dichlorofluoresceindiacetate (DCFH-DA) was obtained from Molecular Probes (Eugene, OR) and all other chemicals used in this study were obtained from Sigma (St. Louis, MO).

\section{Cell culture}

PC-14 cells were provided by Dr. Young Sook Son (Korea Cancer Center Hospital, Seoul, Korea) and maintained in RPMI 1640 media containing 10\% fetal bovine serum, 100 units $/ \mathrm{ml}$ penicillin $\mathrm{G}$ sodium and 100 $\mathrm{mg} / \mathrm{ml}$ strepto-mycin sulfate. Cells were grown at $37^{\circ} \mathrm{C}$ in a humidified air with $5 \% \mathrm{CO}_{2}$.

\section{TGase activity assay}

TGase activity assay was carried out according to the methods described (Folk and Chung 1985). Cells $(5 \times$ $10^{6}$ ) were harvested and homogenized in TBS (100 mM Tris- $\mathrm{HCl}, \mathrm{pH} 7.4$ and $1.5 \mathrm{M} \mathrm{NaCl}$ ) containing $1 \mathrm{mM}$ EDTA, $5 \mathrm{mM}$ benzamidine $\mathrm{HCl}, 1 \mathrm{mM}$ PMSF, $0.5 \mu \mathrm{g} / \mathrm{ml}$ leupeptin and $2 \mu \mathrm{g} / \mathrm{ml}$ aprotinin. The $100 \mathrm{mg}$ homogenate protein and $0.25 \mu \mathrm{Ci}\left[1,4-{ }^{14} \mathrm{C}\right]$ putrescine (S.A. $10^{8} \mathrm{mCi} / \mathrm{mmol}$ ) were added into the $400 \mu \mathrm{l}$ substrate solution $(0.1 \mathrm{M}$ Trisacetate, $0.5 \mathrm{mM}$ EDTA, $10 \mathrm{mM} \mathrm{CaCl} 2,0.5 \%$ Triton X$100,5 \mathrm{mM}$ dithiothreitol and $1 \% \mathrm{~N}, \mathrm{~N}$-dimethylcasein) and incubated at $37^{\circ} \mathrm{C}$ for $1 \mathrm{~h}$. Subsequently, $7.5 \%$ icecold trichloroacetic acid was added to the reaction mixture to stop the reaction and proteins were precipitated overnight at $4^{\circ} \mathrm{C}$, followed by a filtration with a Whatman GF/A filter. The radioactivities of the precipitates were counted by a liquid scintillation counter and the enzyme activity was calculated by the $\left[{ }^{14} \mathrm{C}\right]$ putrescine incorporation rate into dimethylcasein.

\section{Western blot analysis}

Cells $\left(5 \times 10^{6}\right)$ were harvested and homogenized in TBS (100 mM Tris- $\mathrm{HCl}, \mathrm{pH} 7.4$ and $1.5 \mathrm{M} \mathrm{NaCl}$ ) containing 1 $\mathrm{mM}$ EDTA, $5 \mathrm{mM}$ benzamidine $\mathrm{HCl}, 1 \mathrm{mM}$ PMSF, 0.5 $\mu \mathrm{g} / \mathrm{ml}$ leupeptin and $2 \mu \mathrm{g} / \mathrm{ml}$ aprotinin. The protein concentration was determined by the Bradford method (Bradford, 1976) and the protein at $20 \mu \mathrm{g}$ concentration was subjected to $10 \%$ SDS-PAGE. The gel was blotted onto nitrocellulose membrane for $1.5 \mathrm{~h}$ at 1 Ampere and the membrane was incubated with a TGase 2 antibody (polyclonal, Lee et al., 1995) and then secondary antibody conjugated with horseradish peroxidase. The chemiluminescence was performed with a ECL kit according to the manufacturer's instruction.

\section{Measurement of ROS production}

Reactive oxygen species (ROS) production in cells was assessed using 2,7-dichlorofluorescein (DCF) according to the method described (Duranteau et al., 1998; Simizu et al., 1998) with slight modifications. Cells $\left(2 \times 10^{6}\right)$ were treated with diacetate form of the dye (DCFH-DA) at a final concentration of $5 \mu \mathrm{M}$. The esterified form of DCFH-DA can permeate cell membranes and then be deacetylated by intracellular esterases. The resulting compound, dichlorofluorescin (DCFH), is reactive with ROS, mainly $\mathrm{H}_{2} \mathrm{O}_{2}$ or hydroxyl radical, to give a oxidized fluorescent compound, dichlorofluorescein (DCF). Fluore-scence was measured using an excitation wavelength of $488 \mathrm{~nm}$ and emitter wavelength of 525 $\mathrm{nm}$ with $1 \%$ attenuation of the excitation light in a luminescence spectrometer (Hewlett-Packard).

\section{Results}

\section{TGase 2 expression by doxorubicin treatment}

Induction of TGase 2 expression in PC-14 cells treated with doxorubicin was examined at two different concentrations; $0.2 \mu \mathrm{g} / \mathrm{ml}$ or $2 \mu \mathrm{g} / \mathrm{ml}$. The enzyme activity has remained at the basal levels in the cells treated with $0.2 \mu \mathrm{g} / \mathrm{ml}$ concentration of doxorubicin upto $88 \mathrm{~h}$ and began to increase. The cells treated with $2 \mu \mathrm{g} / \mathrm{ml}$ concentration of doxorubicin responded by three-fold elevation of TGase acitivity in a biphasic mode peaking at 10 and $64 \mathrm{~h}$ and returned to a basal level at 40 and $94 \mathrm{~h}$ (Figure 1A). The elevation of TGase activity was accomanied with a concomitant increase of TGase 2 protein. Fig 1B shows elevated TGase 2 protein levels at 16 and $64 \mathrm{~h}$ and lower levels at 0 and $40 \mathrm{~h}$ suggesting that specific activity of TGase 2 remain unchanged during the experimental period. These results indicate that doxorubcin induced a de novo synthesis of TGase 2.

\section{Generation of ROS by doxorubicin treatment}




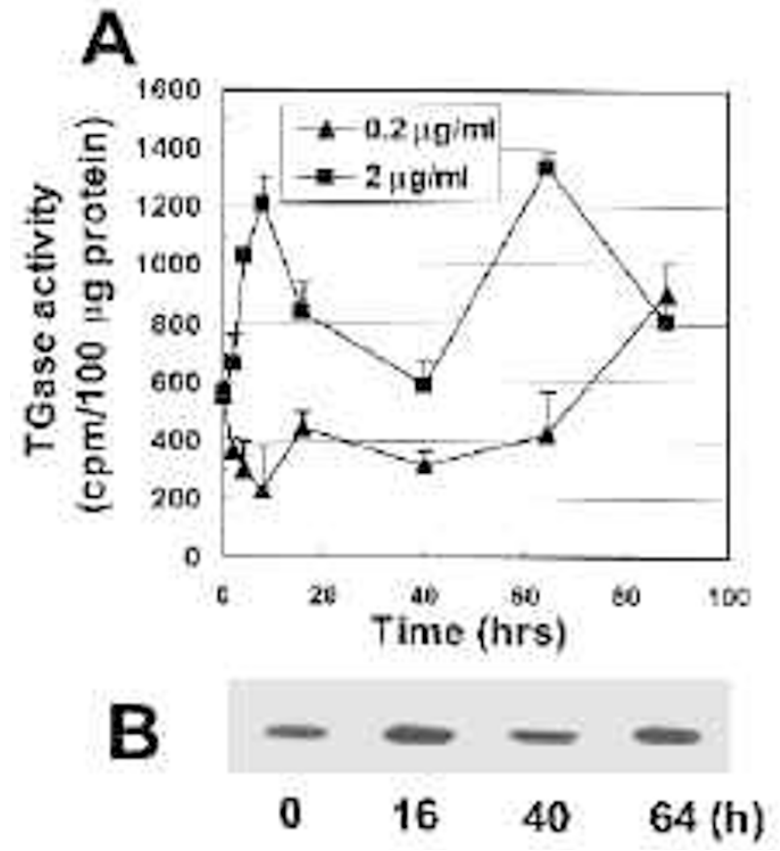

Figure 1. Changes of TGase 2 expression level by the treatment of doxorubicin in PC14 cells. (A) Cells were treated with doxorubicin in a concentration of $0.2 \mu \mathrm{g} / \mathrm{ml}(\boldsymbol{\Delta})$ or $2 \mu \mathrm{g} / \mathrm{ml}(\square)$ as a function of time. Then TGase enzyme activity was measured according to the method described in Materials and Methods. Data represent the mean values \pm standard deviations from 3 experiments. (B) Representative immunoblot of TGase 2 protein from cells treated with $2 \mu \mathrm{g} / \mathrm{ml}$ doxorubicin for indicated time.

Generation of reactive oxygen species (ROS) in PC-14 cells treated with doxorubicin were examined using dichlorofluorescei-diacetate (DCFH-DA) probe. A small but significant increment of relative fluorescence intensity was increased in the cells treated with $2 \mu \mathrm{g} / \mathrm{ml}$ concentration of doxorubicin for $40 \mathrm{~h}$ (Figure 2). This result demonstrates that ROS are generated by doxorubicin within PC-14 cells.

\section{Effects of NAC or GSH pretreatment on doxorubicin-induced TGase 2 expression}

In an effort to investigate a possible inter-relationship of TGase 2 expression and hydrogen peroxide generation in the doxorubicin treated PC-14 cells, the hydrogen peroxide neutralizing agents, $\mathrm{N}$-acetylcysteine (NAC) or glutathione (GSH) were used for conditioning of the cells prior to doxorubicin treatment. As shown in Figure 3 , the pretreatment of the cells with $10 \mu \mathrm{M}$ NAC or 10 $\mathrm{nM}$ GSH for one hour resulted in an inhibition of elevation of TGase 2 expression observed with doxorubicin treatment but rather a significant lowering of TGase enzyme activity without changes in the protein amount. A treatment with $10 \mu \mathrm{M} \mathrm{NAC}$ or $10 \mathrm{nM}$ GSH for $1 \mathrm{~h}$ had

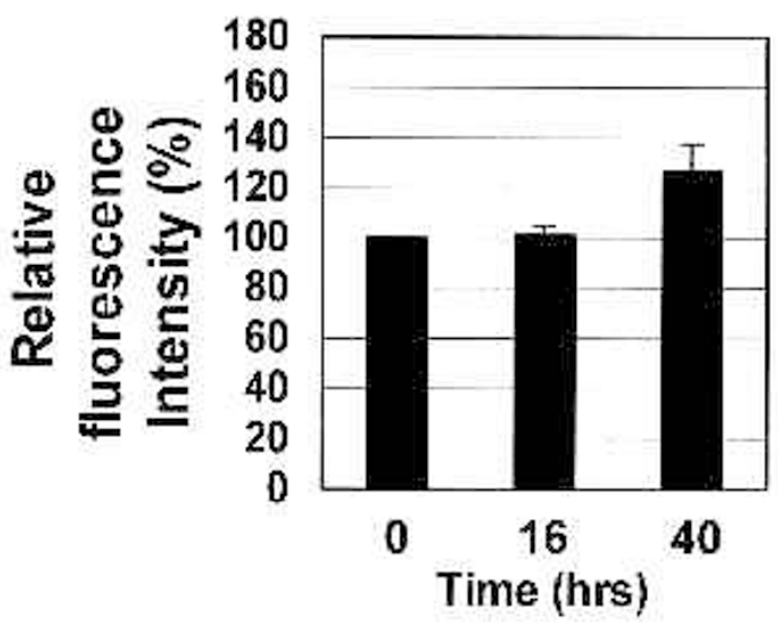

Figure 2. Measurement of ROS generation by doxorubicin treatment in PC-14 cells. Cells were treated with $2 \mu \mathrm{g} / \mathrm{ml}$ doxorubicin as a function of time and the amount of intracellular ROS was measured by the method described in 'Materials and Methods'. Data represent the mean values \pm standard deviations from 4 experiments.

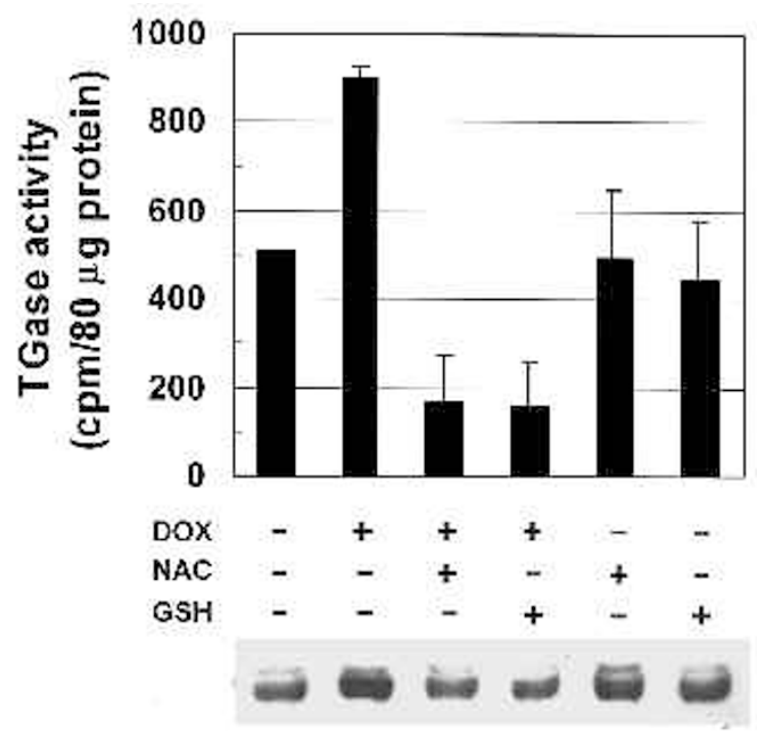

Figure 3. Effect of NAC or GSH pretreatment on doxorubicin-induced TGase 2 expression in PC-14 cells. Cells were pretreated with $10 \mu \mathrm{M} \mathrm{NAC}$ or $10 \mathrm{nM} \mathrm{GSH}$ for 1 hour and then followed by a treatment with doxorubicin in $2 \mu \mathrm{g} / \mathrm{ml}$ concentration for 64 h. TGase enzyme activity was measured according to the method described in 'Materials and Methods' (upper pannel). Data represent the mean values \pm standard deviations from 3 experiments. And the amount of TGase 2 protein was compared by Western blot analysis (lower pannel).

little effect on the enzyme activity in itself (Figure 3). These data suggest that hydrogen peroxide could probably be related to an increase of TGase 2 expression by doxorubicin in $\mathrm{PC}-14$ cells. 


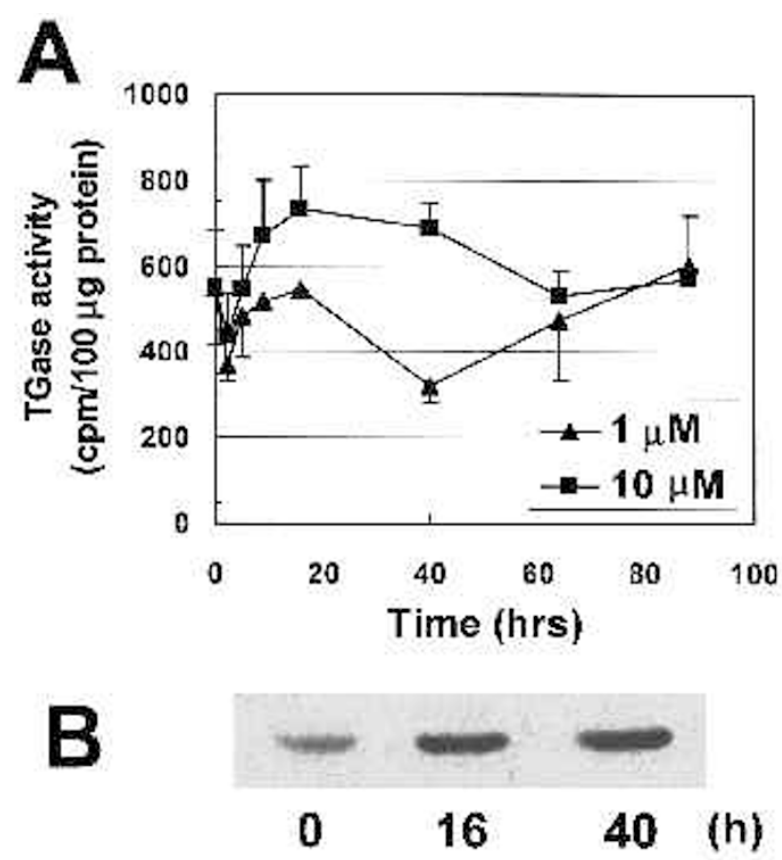

Figure 4. Changes of TGase 2 expression level by $\mathrm{H}_{2} \mathrm{O}_{2}$ treatment in PC-14 cells. (A) Cells were treated with $\mathrm{H}_{2} \mathrm{O}_{2}$ in a concentration of $1 \mu \mathrm{M}$ (s) or $10 \mu \mathrm{M}(\mathrm{n})$ for various times. Then TGase enzyme activity was measured according to the method described in 'Materials and Methods'. Data represent the mean values \pm standard deviations from 3 experiments. (B) Representative immunoblot of TGase 2 protein from cells treated with $10 \mu \mathrm{M} \mathrm{H}_{2} \mathrm{O}_{2}$ for indicated time, respectively.

\section{Increase of TGase 2 expression by hydrogen peroxide treatment}

A poosible affect of hydrogen peroxide exposure of PC14 cells on the expression of TGase 2 were examined. As shown in Figure 4, TGase 2 enzyme activity and protein levels were increased with $10 \mu \mathrm{M}$ hydrogen peroxide treatment within $24 \mathrm{~h}$. All these data suggest that hydrogen peroxide plays a key role in an increase of TGase 2 expression in doxorubicin-treated PC-14 cells.

\section{Discussion}

We have previously reported that TGase 2 expression was increased with the acquisition of resistance to doxorubicin or vincristine, and this increase was one of the mechanism for the acquisition of resistance to these drugs in PC-14 cells (Han and Park, 1999). In addition, the findings that TGase 2-reduced clones showed increased sensitivity to cisplatin as well as to doxorubicin or vincristine suggested the possibility that TGase 2 might play a role in the acquisition of drug resistance through a general cellular protective mechanism other than MDR-related system (Han and
Park, 1999).

In addition, it was recently reported that hydrogen peroxide functioned as a common mediator for apoptosis induced by doxorubicin, vinblastine, campothecin and inostamycin in Ms-1 human small cell lung cancer cells (Simizu et al., 1998). It was also reported that hydrogen peroxide production was a critical event for cisplatininduced cytotoxicity in $\mathrm{S}_{3}$ renal terminal tubular cells (Tsutsumishita et al., 1998). These findings strongly suggest that hydrogen peroxidemay also function as an important mediator for the doxorubicin- or vincristineinduced increase of TGase 2 expression, which might be responsible for cellular defense activity against a variety of cytotoxic agents in PC-14 cells.

In the present study, hydrogen peroxide generated by doxorubicin was shown to mediate an increase of TGase 2 expression in doxorubicin-treated PC-14 cells. According to our data, TGase 2 expression was increased by $2 \mu \mathrm{g} / \mathrm{ml}$ doxorubicin in a biphasic manner, which had two peakes at $8 \mathrm{~h}$ and $64 \mathrm{~h}$ (Figure 1). It is not clear why the two peak of TGase 2 during the 4 days of exposure to doxorubicin. There appeared to be a thresh fold level of the enzyme synthesis. Whether there exists any phenotypic factors regulating TGase 2 in the doxorubicin treated cells are not known at present.

TGase 2 is a sulfhydryl enzyme, of which a cysteine residue in the active site is essential for its activity (Folk, 1980). Therefore, the enzyme is very vulnerable to oxidizing agents including ROS. Actually, the enzyme itself is inactivated by hydrogen peroxide (Jung et al., 1992). Therefore, doxorubicin treatment might inactivate the enzyme activity, but the cellular response to the drug was opposite to the previous view, which suggests the strong possibility of the enzyme-inducing function by the drug. Actually, we have reported that the development of drug resistance to doxorubicin was accompanied by induction of TGase 2 in PC-14 human lung cancer cell line (Han and Park, 1999).

The induction of TGase 2 by doxorubicin treatment could be mediated by hydrogen peroxide, since doxorubicin treatment generated ROS in the cells (Figure 2), and hydrogen peroxide induced the TGase 2 expression (Figure 4). Moreover, we have shown that a long term treatment with hydrogen peroxide of the human primary fibroblast induced the cellular senescence-like changes concomitantly with the induction of TGase 2 expression (Park et al., 1999). The ROS generation including hydrogen peroxide by doxorubicin has been well documented (Doroshow, 1983; Muindi et al., 1984). In addition, the role of hydrogen peroxide or other ROS in the doxorubicininduced TGase 2 expression was confirmed by the effect of NAC and GSH treatment (Figure 2). Both agents are well known as the radical scavengers, blocking the activity of hydrogen peroxide.

It is not clear yet how hydrogen peroxide can induce TGase 2 expression. It should be studied whether 
hydrogen peroxide or other ROS can directly activate the trans-criptional mode of the enzyme or they modulate the activities of transcriptional factors or inhibitors. It has been already reported that ROS could modulate the activity of NF-kappaB, which affected a variety of gene expression (Pinkus et al., 1996; Schmidt et al., 1996). But it is not clearly shown that NF-kappaB or other ROS sensitive transcriptional factors are involved in genetic regulation of TGase 2 ( $\mathrm{Lu}$ et al., 1995).

From these results, it could be concluded that the doxorubicin-induced TGase 2 expression might be mediated by hydrogen peroxide generated by doxorubicin treatment

\section{References}

Batist, G., Tulpules, A., Sinha, B., Katki, A., Myers, C., E. and Cowan, K. H. (1986) Overexpression of a novel anionic glutathione transferase in multidrug-resistant human breast cancer cells. J. Biol. Chem. 261: 15544-15549

Beck, W. (1987) The cell biology of multiple drug resistance. Biochem. Pharmacol. 36: 2879-2887

Birckbichler, P. J., Orr, G. R. and Patterson, M., K. Jr. (1976) Differential transglutaminase distribution in normal rat liver and rat hepatoma. Cancer Res. 36: 2911 2914

Bradford, M. M. (1976) A rapid and sensitive method for the quantitation of microgram quantities of protein utilizing the principle of protein-dye binding. Anal. Biochem. 72 248-254

Bungay, P. J., Potter, J. M. and Griffin, M. (1984) The inhibition of glucose-stimulated insulin secretion by primary amines. Biochem. J. 219: 819-827

Bungay, P. J., Owen, R. A., Coutts, I. C. and Griffin, M. (1986) A role for transglutaminase in glucose-stimulated insulin release from the pancreatic $\beta$-cell. Biochem. J. 235: 269-278

Byrd, J. C. and Lichti, U. (1987) Two types of transglutaminase in the PC12 pheochromocytoma cell. J. Biol. Chem. 262: 11699-11705

Cai, D., Ben, T. and De Luca, L. M. (1991) Retinoids induce tissue transglutaminase in NIH-3T3 cells. Biochem. Biophys. Res. Comm. 175: 1119-1124

Cole, S. P. C., Bhardwai, G., Gerlach, J. H., Mackie, J. E., Grant, C. E., Almquist, K. C. Stewart, A. J., Kurz, E. U., Duncan, A. M. V. and Deeley, R. G. (1992) Overexpression of a transporter gene in a multidrug-resistant human lung cancer cell line. Science 258 : 1650-1654

Davies, P. J. A., Davies, D. R., Levitzki, A., Maxfield, F. R., Milhaud, P., Willingham, M. C. and Pastan, I. H. (1980) Transglutaminase is essential in receptor-mediated endocytosis of $\alpha 2$-macroglobulin and polypeptide hormones. Nature 283: 162-167

Davies, P. J. A., Chiocca, E. A., Basilion, J. P., Podder, S. and Stein, J. P. (1988) Transglutaminase and their regulation: Implications for polyamine metabolism. Adv. Exp. Med. Biol. 250: 391-401

Doroshow, J. H. (1983) Anthracyclin antibiotic-stimulated superoxide, hydrogen peroxide, and hydroxyl radical production by NADH dehydrogenase. Cancer Res. 43 ; 4543-4551

Duranteau, J., Chandel, N. S., Kulisz, A., Shao, Z. and Schumacker, P. T. (1998) Intracellular signaling by reactive oxygen species during hypoxia in cardiomyocytes. $J$. Biol. Chem. 273: 11619-11624

Feng, J. F., Rhee, S. G. and Im, M. J. (1996) Evidence that phospholipase $\delta 1$ is the effector in the $G_{h}$ (transglutaminase II)-mediated signaling. J. Biol. Chem. 271: 1645116454

Fesus, L., Szucs, E. F., Barrett, K. E., Metcalfe, D. D. and Folk, J. E. (1985) Activation of transglutaminase and production of protein-bound $\gamma$-gluta-mylhistamine in stimulated mouse mast cells. J. Biol. Chem. 260: 13771-13778

Fesus, L., Thomazy, V. and Falus, A. (1987) Induction and activation of tissue transglutaminase during programmed cell death. FEBS Lett. 224: 13771-13776

Fine, R. L., Patel, J. and Chabner, B. A. (1988) Phorbol esters induce multidrug resistance in human breast cancer cells. Proc. Natl. Acad. Sci. USA 85: 582-586

Folk, J. E. (1980) Transglutaminases. Ann. Rev. Biochem. 49: 517-531

Folk, J. E. and Chung, S. I. (1985) Transglutaminases. Methods Enzymol. 113: 358-375

Gentile, V., Thomazy, V., Piacentini, M., Fesus, L. and Davies, P. J. A. (1992) Expression of tissue transglutaminase in Balb-C 3 T3 fibroblasts: effects on cellular morphology and adhesion. J. Cell Biol. 119: 463-474

Godwin, A. K., Meister, A., O'Dwyer, P. J., Huang, C. S., Hamilton, T. C. and Anderson, M. E. (1992) High resistance to cisplatin in human ovarian cancer cell lines is associated with marked increase of glutathione synthesis. Proc. Natl. Acad. Sci. USA 89: 3070-3074

Hamilton, T. C., Winker, M. A., Louis, K. G., Batist, G., Behrens, B. C., Tsuruo, T., Grotzinger, K. R., Mckoy, W. M., Young, R. C. and Ozols, R. F. (1985) Augmentation of adriamycin, melphalan, and cisplatin cytotoxicity in drug-resistant and -sensitive human ovarian carcinoma cell lines by buthionine sulfoximine mediated glutathione depletion. Biochem. Pharmacol. 34: 2583-2586

Han, J. A. and Park, S. C. (1999) Reduction of transglutaminase 2 expression is associated with an induction of drug sensitivity in PC-14 human lung cancer cell line. $J$. Cancer Res. Clin. Oncol. (in press)

Harker, W. G., Slade, D. L., Drake, F. H. and Parr, R. L. (1991) Mitoxantron resistance in HL-60 leukemia cells: Reduced nuclear topoisomerase II catalytic activity and druginduced DNA cleavage in association with reduced expression of the topoisomerase II isoform. Biochemistry 30: 9953-9961

Julian, C., Speck, N. A. and Pierce, S. K. (1983) Primary amines inhibit the triggering of B lymphocytes to antibody synthesis. J. Immunol. 130: 91-96

Jung, E. M., Woo, K. M. and Park, S. C. (1992) Metal-catalyzed oxidation-mediated activation of transglutaminase from rat coagulating gland. Korean J. Biochem. 24: 163168

Katoh, S., Nakagawa, N., Yano, Y., Satoh, K., Konoh, H. and Ohkubo, Y. (1996) Transglutaminase induced by epidermal growth factor negatively regulates the growth signal in primary cultured hepatocytes. Biochem. J. 313: 305-309

Lee, K. N., Birckbichler, P. J. and Patterson, M. K. Jr. (1989) GTP hydro-lysis by guinea pig liver transglutaminase. Biochem. Biophys. Res. Comm. 162: 1370-1375

Lee, S. A., Karaszkiewicz, J. W. and Anderson, W. B. (1992) Elevated level of nuclear protein kinase $\mathrm{C}$ in multidrug-resistant MCF-7 human breast carcinoma cells. Cancer Res. 52: 3750-3759

Lee, S. K., Chi, J. G., Jeon, Y. J., Park, S. C., Mori, M. and Chung, S. I. (1995) Expression of transglutaminase $C$ during the prenatal development of human submandibular glands. J. Dental Res. 74: 1812-1816

Lu, S., Saydak, M., Gentile, V., Stein, J. P. and Davies, P. J. A. (1995) Isolation and characterization of the human tissue transglutaminase gene promoter. J. Biol. Chem. 270: $9748-9756$

Marquardt, D., McCrone, S. and Center, M. S. (1990) Mechanisms of multidrug resistance in HL60 cells: Detection of resistance-associated proteins with antibodies against synthetic peptides that correspond to the deduced sequence of P-glycoprotein. Cancer Res. 50: 1426-1430

Mehta, K. (1994) High levels of transglutaminase expression in doxoru-bicin-resistant human breast carcinoma cells. Int. J. Cancer 58: 400-406 
Mian, S., Alaoui, E., Lawry, J., Gentile, V., Davies, P. J. A. and Griffin, M. (1995) The importance of GTP-binding protein tissue transglutaminase in the regulation of cell cycle progression. FEBS Lett. 370: 27-31

Mimmaugh, E. G., Dusre, L., Atwell, J. and Myers, C. E. (1989) Differential oxygen radical susceptibility of adriamycin-sensitive and -resistant MCF-7 human breast tumor cells. Cancer Res. 49: 8-15

Muindi, J. R., Sinha, B. K., Gianni, L. and Myers, C. E. (1984) Hydroxyl radical production and DNA damage induced by anthracyclin-iron complex. FEBS Lett. 172: 226230

Nakaoka, H., Perez, D. M., Baek, K. J., Das, T., Husain, A., Misono, K., Im, M. J. and Graham, R. M. (1994) Gh: a GTP-binding protein with transglutaminase activity and receptor signaling function. Science 264: 1593-1596

Park, S. C., Yeo, E. J., Han, J. A., Hwang, Y. C., Choi, J. Y., Park, J. S., Park, Y. H., Kim, K. O., Kim, I. G., Seong, S. C. and Kwak, S. J. (1999) Aging precess is accompanied by increase of transglutaminase C. J. Gerontol. A. Biol. Sci. Med. Sci. 54; B78-83

Piacentini, M., Autuori, F., Dini, L., Farrace, M. G., Ghibelli, L., Piredda, L. and Fesus, L. (1991) Tissue transglutaminase is specifically expressed in neonatal rat liver cells undergoing apoptosis upon epidermal growth factor-stimulation. Cell Tissue Res. 263: 227-235

Pinkus, R., Weiner, L. M. and Daniel, V. (1996) Role of oxidants and anti-oxidants in the induction of AP-1, NF-kappaB, and glutathione S-trans-ferase gene expression. J. Biol. Chem. 271; 13422-13429

Ross, W., Rowe, T., Glisson, B., Yalowich, J. and Liu, L. (1984) Role of topoisomerase II in mediating epipodophyllotoxin-induced DNA cleavage. Cancer Res. 44: 5857-5860

Russell, D. H. and Womble, J. R. (1982) Transglutaminase may mediate physiological effects of endogenous amines and of amine-containing therapeutic agents. Life Science 30: $1499-1508$

Scanlon, K. J., Jiao, L., Funato, T., Wang, W., Tone, T., Rossi, J. J. and Kashani-Sabet, M. (1991) Ribozyme-mediated cleavage of c-fos mRNA reduces gene expression of DNA synthesis enzymes and metallothionein. Proc. Natl. Acad. Sci. USA 88: 10591 10595

Scanlon, K. J., Ishida, H. and Kashani-Sabet, M. (1994) Ribozyme-mediated reversal of the multidrug-resistant phenotype. Proc. Natl. Acad. Sci. USA 91: 11123-11127
Schmidt, K. N., Amstad, P., Cerutti, P. and Baeuerle, P. A. (1996) Identi-fication of hydrogen peroxide as the relevant messenger in the activation pathway of transcription factor NF-kappaB. Adv. Exp. Med. Biol. 387; 63-68

Scott, K. F. F., Meyskens, F. L. Jr. and Russell, D. H. (1982) Retinoids increase transglutaminase activity and inhibit ornithine decarboxylase activity in chinese hamster ovary cells and in melanoma cells stimulated to differentiate. Proc. Natl. Acad. Sci. USA 79: 4093-4097

Simizu, S., Takada, M., Umezawa, K. and Imoto, M. (1998) Requirement of caspase-3(like) protease-mediated hydrogen peroxide production for apoptosis induced by various anticancer drugs. J. Biol. Chem. 273: 26900-26907

Slater, T. F. (1984) Free-radical mechanisms in tissue injury. Biochem. J. 222: 1-15

Sullivan, D. M., Eskildsen, L. A., Groom, K. R., Webb, C. D., Latham, M. D., Martin, A. W., Wellhausen, S. R., Kroeger, P. E. and Rowe, T. C. (1993) Topoisomerase II activity involved in cleaving DNA into topological domains is altered in a multiple drug-resistant chinese hamster ovary cell line. Mol. Pharmacol. 43: 207-216

Tsutsumishita, Y., Onda, T., Okada, K., Takeda, M., Endou, H., Futaki, S. and Niwa, M. (1998) Involvement of $\mathrm{H}_{2} \mathrm{O}_{2}$ production in cisplatin-induced nephrotoxicity. Biochem. Biophys. Res. Comm. 242: 310-312 